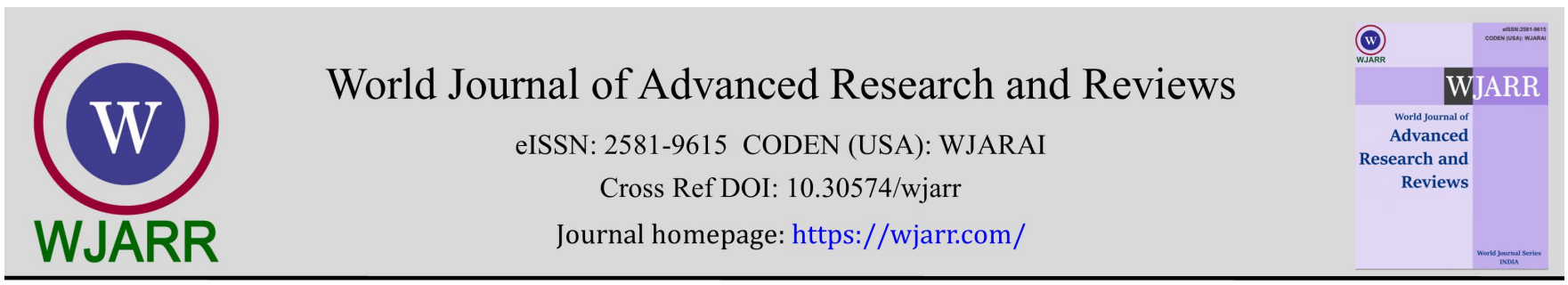

(REVIEW ARTICLE)

\title{
The Colonialism and Post Colonialism Diaspora and its unique effect on the world
}

\section{culture over the years}

\author{
Dr Sumanta Bhattacharya ${ }^{1,}{ }^{*}$ and Bhavneet Kaur Sachdev ${ }^{2}$ \\ ${ }^{1}$ MAKAUT, Public-Foreign-Defence Policy, MPI (oxford University) ORCID ID: 0000-0003-2563-2787. \\ 2 Political Science hons (Calcutta University), Development studies, ORCID ID: 0000-0001-9156-0086.
}

World Journal of Advanced Research and Reviews, 2021, 12(03), 108-113

Publication history: Received on 17 October 2021; revised on 03 December 2021; accepted on 05 December 2021

Article DOI: https://doi.org/10.30574/wjarr.2021.12.3.0991

\begin{abstract}
Indian Diaspora has never been acknowledged and been neglected in India's cultural diplomacy for long period of time but their contribution and immense leverage in local communities and government has been recognised in recent years and the Indian Government has taken some measures to link with the diaspora and make them partners in India's growth and part of International relation. Diaspora Diplomacy plays a crucial role in the foreign policy and in increase economic, political and defense cooperation between different countries. Indian communities are spread across the global in 6 continents and 125 countries, Indian Diaspora is categorized into old, new and gulf Diaspora according to their labour characteristics. The success of Indian entrepreneurs, scientist, academics, media personalities, filmmakers, IT professionals, CEOs in the US has created trust in India's intellectual abilities abroad. It has been a major source in branding India as a source of well-educated and hard working professionals. Ethnic Indians particularly in New Diaspora countries have become known for their economic, professional academic, scientific and artistic successes and general peaceful integration. The government of India has taken many initiatives for their betterment and organize various programmes for being the India Diaspora close to their host country and also to resolve the issues and challenges faced by the government from the Indian Diaspora.
\end{abstract}

Keywords: India Diaspora; Diaspora Diplomacy; International relation; Economic growth; Peaceful integration

\section{Introduction}

India Diaspora is said to be over 300 million which is the largest diaspora in the world as per the UN Department of Economic and Social Affairs. The diaspora covers practically every part of the world. it numbers more than a million each in eleven countries while as many as twenty-two countries have concentrations of at least a hundred thousand ethnic Indians. The diaspora is very special to India, residing in distant lands, its members have succeeded consistently in their chosen professions by dint of their single-minded dedication and hard work and kept their emotional, cultural and spiritual links with the country of their origin. The Government of India recognizes the importance of Indian Diaspora as it has brought economic, financial and diplomatic benefits to India. The movement of people from India can be traced back to the ancient times which has continued till today. An interesting story of cultural exchange that the people of India have had with the rest of the world. The long journey that monks and saints undertook for the spread of knowledge, peace and love. The historical evolution of the Indian Diaspora which was 30 million goes back at least two thousand years. The first migration from what the modern day India was around the time of Emperor Kanishka in the first century AD. In modern times,large scale Indian migration took place as a result of abolition of slavery in British, French and Dutch colonies in 1834, 1846 and 1987 respectively. Captured Labour was recruited for colonial plantations in Asia, Africa, Caribbean and the Pacific. During the colonial period, Indians were traded as slaves by Portuguese, Dutch, French and English imperialist. Indians were taken over as soldiers to develop plantation economies, construct railway

\footnotetext{
* Corresponding author: Dr Sumanta Bhattacharya
}

MAKAUT, Public-Foreign-Defence Policy, MPI (oxford University) ORCID ID: 0000-0003-2563-2787.

Copyright (C) 2021 Author(s) retain the copyright of this article. This article is published under the terms of the Creative Commons Attribution Liscense 4.0. 
networks and to serve s soldiers in the imperial military establishment in far pats in the 19th century. Over two million men fought on behalf of the empire in numerous wars, including the Boer war and the two world wars and some remained behind to claim that the land on which they fought as their won. In the post world war II era the dispersal of Indian Labour and professionals has been a nearly world wide phenomenon. Indians and other South Asian provided the labour which helped in the reconstruction of war-torn Europe particularly the United Nations and Netherlands. These workers and soldiers were often accompanied and followed by large number of Indian traders and professionals under the free passage system. The colonial link has resulted in the formation of small Indian communities in UK, Australia and North America. Many Gujarati left for East Africa in the early $20^{\text {th }}$ century, while ethnic Indians are a small but wealthy minority in the US, the UK, and the countries of the new diaspora, they constitute $40 \%$ of the population in Fiji, Trinidad, Guyana Reunion and Suriname and 70\% of Mauritius -all old diaspora countries.

\section{Research Methodology}

For the following research paper, we did a survey where we asked questions to the families where one of the member has been working in an foreign country, followed by International relations student and Policy Analyst. Secondary data was also collected from different journals on the perspective of Indian Diaspora.

\section{Objective of the Research Paper}

The main areas of exploration in this paper incorporates

- An evolution on the Indian Diaspora over the years

- What are the problem being faced by the Indian community abroad

- What measures has the government taken to protect the rights and needs of Indian Diaspora community

\section{Literature Review}

Over the past two centuries India has possibly achieved the world's most diverse and compound migration history, forming the modern diaspora. It covers six continent and 125 countries. We define the Indian diaspora into three subset the old Diaspora, New Diaspora and the Gulf Diaspora. They were and are created by labour migrants-unskilled labour starting two century ago and highly skilled post the mid 1960s. The mutual thing between all the three diaspora is that they all are migrants. The recent migration sets of skilled and unskilled labour went to the developed countries like the US, UK, Canada, Australia and New Zealand and formed part of the new Indian Diaspora, on the other hand the lower, semi-skilled and unskilled settled in the gulf region.. India's diaspora is small compared to the country's domestic population is excessive skilled, educated and wealthy, the Indian Highly skilled migrants have amplified considerably over the past decades as globalization of trade, capital and labour has taken hold. It is $2 \%$ of the India's population, the total wealth. The income of this community is estimated to be UD \$ 400 billion that is $20 \%$ of India's GDP. The highachieving groups incorporate the US Senators, Nobel laureates, CEOs of Fortune 500 companies, entrepreneurs galore and prize winning authors. The overseas Indian community is comprised of doctors, scientist, engineers, technology finance professionals in their respective host countries and in the US now forms one of the most cultivated, skilled and wealthy communities. Today most importance source of consideration to India comes from the Gulf States which has a large population of lower skilled workers. In order to fully capitalize the potential of its diaspora India clearly needs to find ways to better leverage the overseas Indian community for investment, transfer of know-how and R\&D. Western countries which are having ageing population and lack of science and engineering professionals, are actively attracting Indian doctors an professionals and by some estimation $10 \%$ of the physicians trained in India have already migrated. Many countries have Indians elected to major public office. In Canada, there are many MPs and Ministers of Indian origin in that country 's parliament, the Canadian house of Commons. In the UK, eight Indian candidates incorporating two women have been elected to the British Parliament, and eight members of the House of Lords are of Indian origin, The success of Indian entrepreneurs, scientist, academics, media personalities, filmmakers, IT professionals, CEOs in the US has created trust in India's intellectual abilities abroad. It has been a major source in branding India as a source of welleducated and hard working professionals. Ethnic Indians particularly in New Diaspora countries have become known for their economic, professional, academic, scientific and artistic successes and general peaceful integration. 


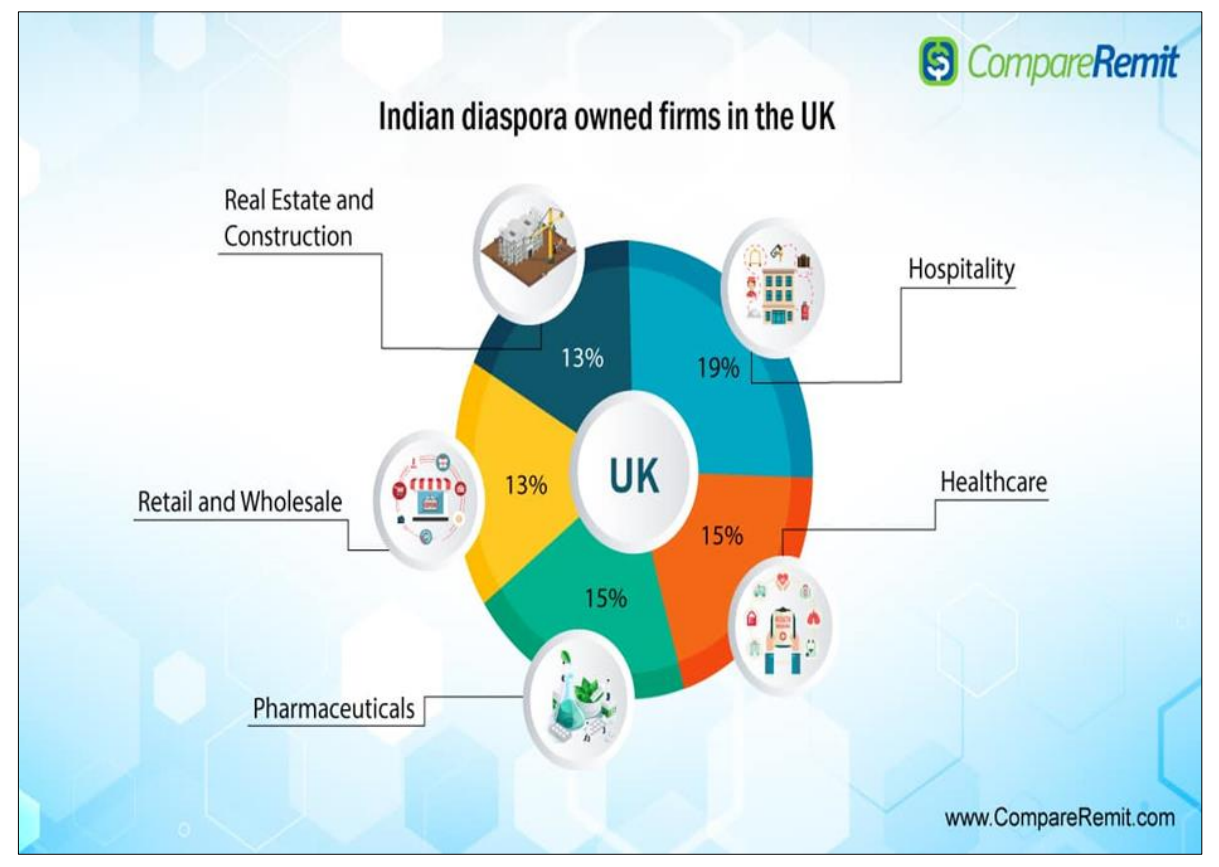

Figure 1 Different India Diaspora earned firms in UK

\section{Findings}

Indian Diaspora is a collective term used for approaching people who have migrated from India and the states are within the border of the Republic of India, it constitutes NRIs(Non-Resident Indians) PIOs (Persons of Indian Origins) and SPIOs (Stateless People of Indian Origins). The NRIs are Indian citizens staying abroad for indefinite period for different purpose and the PIOs are Overseas Indians who have become citizen of the countries of their settlement. Jawaharlal Nehru had taken keen personal interest in the welfare of overseas Indian communities. However, after Independence he gave priority to the larger foreign policy goals. He abolished the ministries of overseas Indian Affairs in 1947. Anticolonialism and Non-Alignment became major pillars of Indian foreign policy. He advised overseas Indian communities to fully identify with the country of their residence. It was Rajiv Gandhi who felt that Indian in the developed world could be an asset in realizing his vision of India of $21^{\text {st }}$ century. The Apollo and Escort Hospitals established by NRI doctors brought a major change in the tertiary health sector. It was under the Prime Minister ship of Rajiv Gandhi that changed the diaspora policy by inviting Indians abroad participate in nation building of their nationality.

The First test of the new Diaspora policy came in 1987 when outset Indian majority government in Fiji and reduce them to second class citizen. Rajiv Gandhi in a major quitting from established policy protested spiritedly imposed trade penalty against Fiji. Got it expelled from the Common Wealth and raise the issue at the United Nations. This mystified those Fiji Indians who did not want to disturb the race relation in Fiji but energized the Indian Diaspora generating trade in them that Indian would be salient witness as it was in the past to discrimination, racism and disenfranchisement of Indians abroad.

Indian Diaspora has never been acknowledged and been neglected in India's cultural diplomacy for long period of time but their contribution and immense leverage in local communities and government has been recognized in recent years and the Indian Government has taken some measures to link with the diaspora and make them partners in India's growth and part of International relation. With globalization taking grounds, diaspora engagement has become an important component of foreign policy to be leveraged for economic, political and strategic objectives. If there is any topic on which all the political parties agree is the imperative need to include overseas Indians in the India's economic development and to take care of their needs. Successive governments have been trying to give more and more concessions to them as acknowledged to their contribution by way of consideration, investments, lobbying for India, promoting Indian culture abroad and for building a good image of India by their creative and work. The Indian Diaspora today constitutes an important and in some respects unique forces in world culture. The government of India has introduced many schemes to cater to the needs of Indian Diaspora by providing them a detailed information on various schemes introduced by the government of India for them. After India and overseas Indians rediscovered each other under Rajiv Gandhi, there came a host of measures such as separate Ministry of Overseas Indian Affairs, the Persons of 
Indian origin card, Pravasi Bharatiya Divas, Pravasi Bharatiya Samman Award, Overseas Citizen of Indian Card, NRI funds and voting rights for Indian citizens abroad,.

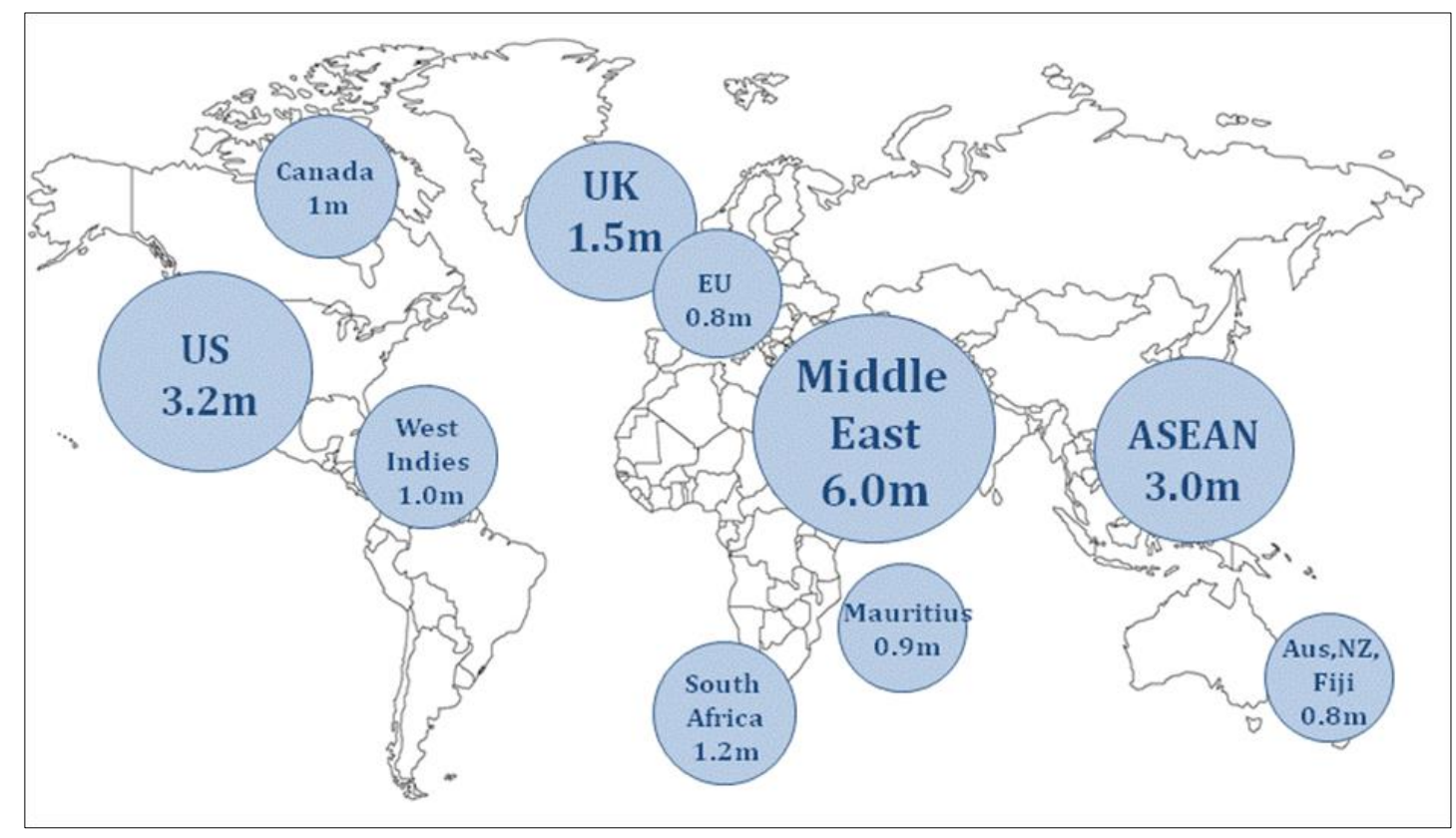

Figure 2 Indian Diaspora in different countries

The use of smart power a mix of India's hard and soft power assets including our large diaspora has played a prominent role to achieve India's foreign policy. The Indian Diaspora is now increasingly active in local politics in the host country, either being a part of the government or leading the government. Diaspora diplomacy has resulted in the succession of a number of foreign policies for instance setting up of India caucus in the US congress and signing of India-US nuclear deal.

Prime Minister Narendra Modi has made Diaspora an important element of his foreign policy and during his foreign visits, he has addressed mammoth meetings of the community to project India's priorities and needs. However he did not address any of the demands or announce any new plans for removing their grievances like travel issues and protection of their properties in India. The merging of the Ministry of Overseas Indian Affairs with the Ministry of External Affairs is regarded as a negative step. The lack of diaspora conference and wards is also causing problem in the diaspora.

Together with new hopes and expectation we also have fears and concern about the overseas communities. The volatility in West Asia together with the fall in oil prices caused massive return of Indian nationals curtailing, payment and making demand on domestic jobs. The gulf countries will require foreign workers for some more times, but India's relation with many have been in an employer -employee mode. India has organized massive evacuation on its workers during disturbances in the Middle -East Even more serious is the suspicious that some Indians are travelling to the Islamic states areas either to join the jihad or to settle there. which is regarded as a promised land. India carried out a major re-orientation of its Economic and Foreign Policy in the wake of major foreign exchange crisis. end of cold war and dissolution of the Soviet Union technology led growth of $18^{\text {th }}$ and $19^{\text {th }}$ and achievements of professionals have launched Indian diaspora to a very high position by the $19^{\text {th }}$ century in the USA.

Every year since 2003 India is celebrating Pravasi Bharatiya Divas every year in New Delhi, it is organized with the aim to develop consciousness of the concept of global Indian family and to develop a web-like relationship between India and all its diaspora community to create better awareness about diaspora among Indian and vice versa to define India's new approach towards Diaspora and to make paramount announcement on diaspora, the government has started a scheme for overseas citizenship, it has opened a new chapter with overseas Indian communities the Pravasi Bharatiya Divas clearly explains the government new scheme, several welfare measures Pravasi Bima Yojana was announced for Indian workers abroad, an internship programme for the youth of the diaspora, and has granted 250 million rupee and suitable land for the establishment of the programme. The government has taken several initiatives for involving the Indian Diaspora round the world which incorporates measures like Pravasi Bharatiya Divas which is one of the largest Diaspora participation in the world $\mathrm{m}$ the ministry organises various other programmes which involve the participation 
of people such as Regional Pravasi Bharaiya Divas, Pravasi Bharatiya Divas in foreign countries, Know India programmes, study India programme, Scholarship Programme for Diaspora citizens, Tracing the roots and issues overseas citizen of India, cards for eligible applicants from the Indian Diaspora abroad irrespective of their region, caste and creed.

The Ministry of Overseas Indian Affairs has taken initiative for the welfare of Indian workers abroad In addition to the existing agreements with Jordon, and Qatar, with Kuwait, UAE, Oman and Malaysia, the Ministry has signed bilateral agreements, The Ministry proposes to sign with important accepting countries of the Central and Eastern Europe and Asia to expand bilateral partnership, overseas employment market for Indian workers, particularly for the skilled labourers, Helpline has been established as part of overseas workers resources centre social security agreements have been signed with a number of countries in Europe, it has also run campaign on TV to educate Indian workers to curtail the malpractices of agents. The Ministry has taken initiative to protect Indian married women who are married to NRI, with major publicity effort to educate prospective brides and parents. Modest amount has been sanctioned for legal representatives and have signed agreements with many foreign NGO s to protect married Indian women, National Commission for Women has set up a cell to deal with this issue.

Liberalization of dual citizenship, establishment of a diaspora knowledge network, improved remittance facilities, followed by the establishment of a PIO university, Creation of Indian overseas Facilitation Centre in partnership with confederation of Indian Industry, Opening of Council for promotion of overseas employment, Facilitating Diaspora philanthropy including establishment of an Index Development Fund, Facilitating practice by diaspora professionals in various fields in India, establishment of an overseas workers resource centre, establishment of a global advisory council of people of Indian origin and construction of Indian community welfare fund in 18 countries and some of the initiative taken by the government of India over the years to protect and fulfil the needs to its citizen abroad.

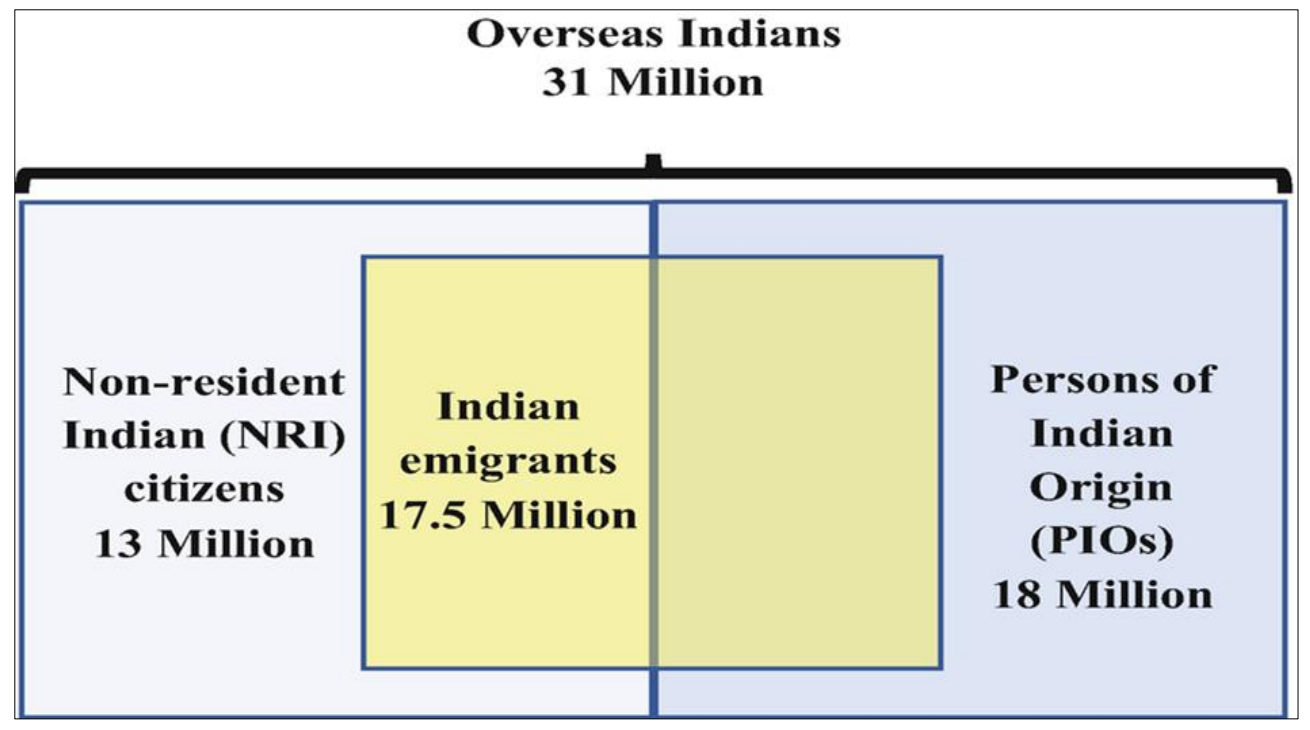

Figure 3 Total India Diaspora both NRI and PIOs

There are demands which are kept in front of the government by Indian diaspora like heterogeneous diaspora, the diaspora from the gulf wants support for welfare issues, like people from wealthier nations look for investment opportunities and the Indian communities in some countries wants to reconnect with their countries on cultural basis for instance in Fiji and Mauritius, Anti-Globalization, with the rise in anti-globalization waves, we see an increase in hate crimes against the Indian community followed by the West Asian Crisis, the fall in oil prices has resulted in the return of massive people back to India and making demand for domestic jobs followed by which we have the challenge of returning diaspora, people who went to West Asia were semi skilled laborers who were mainly involved in the infrastructure sector, which will be a boom for India, regulatory cholesterol, there is lack of adequate of the Indian system diaspora to resolve grievances like red tape, distrust of the government, multiple clearness and hurdles in fulfilling the needs and opportunities presented by the Indian diaspora, India also has a lot of negative campaigning, foreign funding coming from abroad and rise of separatist movement. these are a few challenges which India needs to overcome. 


\section{Conclusion}

The nature of involvement with Diaspora has changed on the basis of time and need, because of extraordinary spread and geographical diversity, the policy of participation has to be flexible and made to suit each layer of Diaspora. This approach towards the workers in the gulf is primarily welfare oriented and remittance centric, engagement with the developed countries has to be multifaceted and aimed at making India a knowledge powerhouse, their strengths have to be promoted for political lobbying, image projection and economic growth of India. In order to amplify communication and advancement in transportation and the global reach of media are creating a major change in the nature of relationship between diaspora and the country of origin. Diaspora diplomacy lay a vital role in the over all development of the country and we have many instance of how Diaspora diplomacy had helped in strengthening bilateral relations.

\section{Compliance with ethical standards}

\section{Acknowledgments}

Dr. Jayanta Kumar Ray: National Research Professor, Ministry of Human Resource Development, GOI, Former Centenary Professor of International Relation, Department of History, CU, and Institute of Foreign studies, CU and Honorary Consultant for Research in Indo-Bangladesh Relations, Kolkata, Former Chairman, Maulana Azad Kalam Azad Institute of Asian Studies, Kolkata. Member of IDSA.

Shakti Sinha: IAS, Honorary Director, Atal Bihar Vajpayee Institute of Policy Research and International Studies.

\section{Disclosure of conflict of interest}

The authors hold no conflict of Interest.

\section{References}

[1] Ellen Bal and Kathinka Sinha Kerkhoff, Religious identity, Territory and Partition: India and its Muslim Diaspora in Surinam and the Netherland National and Ethnic Politics.2008; 14(2)

[2] Papiya Ghosh, 2016, January, Partition and the South Asian Diaspora. Routledge, IBSN - 9781138662346.

[3] Tony Ballantyne. 2006, August,Between Colonialism and Diaspora. Duke University Press.

[4] RK Mishra. Colonialism, 2012, November, Post Colonialism and Diaspora in terms of Translation. Sematic Scholar

[5] Dr Mahalingam. India's Diaspora policy and Foreign Policy: An Overview. GRFDT

[6] Ministry of External Affairs GOI, India's Foreign Policy, National Security and Development.

[7] Singh N, Koiri P. Migration, Diaspora and Development impression from India, Journal of Enterprising Communities People and Places in the Global Economy. 2012; 12(2).

[8] Amba Pande. Conceptualising Indian Diaspora: Diversities within a common Identity, Economic and Political Weekly. 2013; 48(49).

[9] Amba Pande. India and its Diaspora: Charting New Avenues of Engagement, International Studies, SAFE JOURNALS. 2018.

\section{Author's Short Biography}

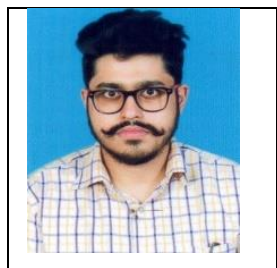

Dr Sumanta Bhattacharya is a Research Scholar at MAKAUT and a Public-Defence-Foreign Policy Analyst. He has 180 research papers, 27 Patents and 27 Book chapters, holds the record for maximum number of degree courses, have won International and national awards for his excellences in Education and Policy Making 